\title{
Seeding a culture of remembering
}

Book review by Deirdre Helfferich

University of Alaska School of Natural Resources and Extension

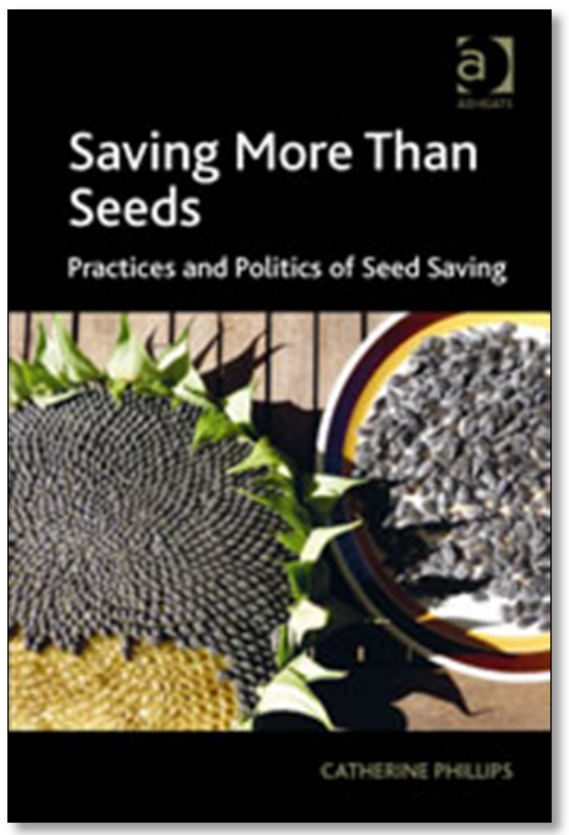

\section{Saving More Than Seeds: Practices and Politics of Seed Saving}

Phillips, C. (2013). Saving more than seeds: Practices and politics of seed saving. Surrey, UK: Ashgate, 286 pages. Available as hardcover and ebook. Publisher's website: http://www.ashgate.com/ isbn/9781409446514

Published online June 18, 2014

Citation: Helfferich, D. (2014). Seeding a culture of remembering [Book review of Saving More Than Seeds: Practices and Politics of Seed Saving. Journal of Agriculture, Food Systems, and Community Development, 4(3), 209-212.

http://dx.doi.org/10.5304/jafscd.2014.043.015

Copyright (C) 2014 by New Leaf Associates, Inc.

$F_{\text {heser }}$ or thousands of years gardeners and farmers have practiced basic plant breeding by selecting those plants deemed of value and saving their seed, tubers, rootstock, etc., to grow and care for them for another generation. Catherine Phillips uses the term seed saving in this broad and traditional sense throughout her book Saving More Than Seeds: Practices and Politics of Seed Saving. This long process of agricultural adaptation has resulted not only in the survival of species and strains of plants with qualities humans deem desirable, but also in the creation of rich cultural traditions as well (think

Deirdre Helfferich is a writer, editor, and graphic designer for the University of Alaska School of Natural Resources and Extension. She was a founding member of the Alaska Food Policy Council and is director of Growing Ester's Biodiversity, the seed library program of the John Trigg Ester Library. She can be contacted at +1-907-479-3368; JTEL, P.O. Box 468, Ester, Alaska 99725 USA; or estereditor@gmail.com. cacao, henna, garlic, poppy). While we have saved their seeds, bulbs, and tubers, plants have profoundly affected us, even providing the foundation for civilization, some have argued (through, appropriately, grain for beer and thus, fittingly, politics (Hayden, 2013)).

Over the last century and a half, researchers and agriculturalists have sped up the adaptation process through the application of genetic technologies and the development of new breeding techniques. Agrobiodiversity, seed saving, and longstanding cultural traditions, however, are disappearing. Measures ostensibly designed to protect the agricultural sector and seed growers have produced negative consequences. For example, intellectual property rights and trade treaties have instead constrained the livelihood of farmers and the rights of gardeners. This has contributed to there being fewer producers and breeders. As a 
result, the public faces less variety and public accountability, and more genetic and economic vulnerability.

The global market's commodity approach, which requires only a few varieties and broad approximate adaptation, disregards the importance of local knowledge and specific adaptation of plants to myriad habitats and conditions. But local and indigenous knowledge of crops may be vital to the resilience of agriculture in the face of climate change (many sources discuss this issue; for an overview, see Swiderska, Song, Li, Reid, \& Mutta, 2011). As argued by Phillips, it is not just in First Nations peoples and non-Western countries that this knowledge may be found and cultivated.

Phillips' book focuses on the seed industry and seed saving in Canada and is a welcome and important addition to the literature on the modern seed industry and food movements. Some of the most refreshing prose in the book arises from the author's original research on the attitudes and practices of Canadian seed savers. Phillips illustrates the complexities of the relationships among seeds, seed savers, seed sellers, plant breeders, farming associations, government regulators and policy makers, and, of course, transnational corporations such as Monsanto.

In Chapter 1, Starting with Seed, Phillips first reflects on the philosophical question of agency, in other words, the capacity to act or influence who and what is around us. The author describes her book as exploring "the ethics and politics of seed saving" and "an effort to challenge our thinking about the present realities and future possibilities of seed saving" (p. 7). Part of this is moving humans from the center of things and allowing for nonhuman agency, "the idea that agency is more distributed and relational rather than concentrated in people" (p. 7). After all, seeds are alive—but more, seeds and people have relationships with each other. I was not expecting to read a book of philosophy and ethics, so these sections took me by surprise. Phillips also provides chapter outlines here.

In Chapter 2, Rethinking Practice, Agency and Worldly Engagements, Phillips elaborates on the experience and practice of seed saving in the decentering of human beings as the agencies of change. She also remarks on how "other things intellectual property rights, gene banks, bacterial DNA, policy proposals - make appearances, shaping and being shaped by seed saving" (p. 26). These first two chapters provide the ethical and thematic background that frames the context of the rest of the book. While Chapter 2 was much more dense and somewhat unevenly written, it still laid a fascinating and important grounding for the following chapters.

Phillips describes Chapters 3, 4, and 5 as being about "seed-people orderings different from, but entangled with seed saving" (p. 11). In Chapter 3, Reordering with Corporations, Phillips reviews the neoliberal, corporate reordering of the seed industry, describing international agreements and their influence on Canadian (and other countries') domestic policies, particularly with regard to commodification and extreme intellectual property rights and patenting. Commodification in and of itself is not a problem for many seed savers, she observes, as they do order from seed companies to refresh their stock, source rare or unusual varieties not carried by larger companies, or support local business, and/or obtain locally adapted seed. Seed savers' relationships with their seed and their seeds' histories, as well as with the companies that carry them, is important to seed savers, as she illustrates with many quotes. Yet, when commodification is carried to the extreme of creating dependence rather than interdependence, seeds and agriculture may suffer. As the author points out, what constitutes "the best seed" is not necessarily the best for all.

Phillips shows how the neoliberalization of the economy's agricultural sector, and its objectification of seeds as natural resources, commodities, and patentable items are a "technopolitical reordering of seeds." This enables "collaborations between governments and seed corporations [to] facilitate commercial market expansion and regulatory constraint of seed saving" (p. 35). The problem of the contamination of the Canadian flaxseed crop with GMOs and the subsequent collapse of the market was especially troubling. Phillips describes how seed certification, rather than "protect[ing] growers from dishonest seed sellers" as intended, has become a way instead to govern all 
aspects of growing specific crops, and "though the pedigreed seed process and its classes remain unaltered, industry now turns to its advantage provisions once used to protect growers from profiteers. In promoting certified seed, industry does more than advocate quality seed - it attempts to enclose seed saving practices, expand certified seed markets and increase opportunities for markets" (p. 45).

In Chapter 4, Configuring Rights, Phillips admirably and fairly addresses the complexities of intellectual property rights. She includes the more subtle issues associated with plant breeders' rights and certification of seed in her discussion, exploring topics on how plant breeders are affected by international treaty and what the establishment (or loss) of rights means in a philosophical sense. Phillips pinpoints the effects on seed savers, farmers, and the seed involved. Her calm treatment of the legal and broader ethical and political issues in the sensationalized Percy Schmeiser case was refreshing (Schmeiser was sued by Monsanto for patent infringement when RoundUp-resistant canola was found growing in his fields). Phillips provides chilling insight into the restrictions the government has increasingly placed on small-scale seed saving by the public and by farmers, and the lack of government sensitivity to the importance of public engagement. "Many of the political decisions related to seed-people relations are considered by governments - including Canada's - to be technical matters, and as such, the underlying beliefs and priorities need not be discussed" (p. 86). Phillips illustrates how many of Canada's regulations and restrictions on seed saving relate directly to the adoption of international treaties such as the Union Internationale pour la Protection des Obtentions Végétales, or UPOV.

In Chapter 5, Securing Accessions, Phillips delves into the issue of genebanking, arguing that the practice is flawed for several reasons. First, it reinforces inequity within seed saving by strengthening the divisions between breeders and farmers as well as Northern and Southern hemispheres (rich and poor). Second, selection is often based on what is deemed "useful," ignoring other values, such as sheer fun, and also the vast potential and possibilities that are still left to be explored or are simply unknown. Last, one should not detach seeds from their culture and histories. Phillips also discusses regeneration failure due to lack of funding and the odd potential for seed adapting to life in a gene bank rather than life in the field.

Chapters 6 and 7, Learning Seed Saving and Reconstituting Worlds Together, are a reflective look on the individual learning process of seed savers, and how seed savers grow to see themselves and their world as a result of their experiences. Phillips quotes from many individual gardeners and seed savers who bring many issues and viewpoints to readers. Phillips explores questions of responsibility toward seed, toward its history and the families who have nurtured it, and the full meaning of stewardship. The development of small businesses as a result of starting in seed sharing, learning through practice, and many other meaningful acts of saving and sharing plants are all lessons in interconnectedness.

Chapter 8, Resisting, Remaking and More, addresses the political nature of seed saving, which can result in political engagement and serve as a way to resist corporate seed ordering and commodification. In particular Phillips focuses on cooperation among seed savers, writing, "the isolated individual of neoliberalisation is countered as savers function necessarily as part of collectives" (p. 204). This statement, however, is in contrast to the lack of discussion of seed libraries throughout the book. A seed library's mission is to preserve through propagation and dissemination, which in turn leads to evolution, rather than to employ methods of isolation and conservation as in a gene bank. Seed libraries are less common in Canada than in the United States, but are prevailing centers of seed-saver activity. They host seed swaps, fairs, and workshops - all of which are activities that the author identifies as opening the possibilities of networking. While Phillips does use the example of the Heirloom Seed Sanctuary in Kingston, Ontario, as an example of "fostering collective belonging," useful to her personally for the information shared and connections made with other savers, she only briefly elaborates on community seed collections like these. In one instance she even goes so far as to state: 
Community-based seed libraries and sanctuaries, like this one [Heirloom Seed Sanctuary], exemplify savers' efforts to build upon their ongoing informal relations by expanding learning, collections and connections. (p. 203)

So why not explore community-based seed libraries and sanctuaries more thoroughly if they exemplify her overall topic, especially in contrast to genebanking? Phillips is careful to explore in meticulous detail the ramifications of seeds and human society, but here she does not. Disappointingly, the philosophical, political, sociological, agroecological, and economic importance of these institutions and of their seed-human relations will have to be considered further in another book.

Aside from this one gap, Phillips covers her topic in depth, producing a thoroughly researched, well written, and well structured work. Her subject matter is carefully placed in larger contexts of ethics, history, politics, economics, property rights, and the human - and nonhuman - experience. Despite the quiet, thoughtful tone and scholarly approach to her subject, the author has written a book that exercised both my intellect and my emotions - at times quite strenuously and loudly! I highly recommend her book to agricultural appointees in government; academics interested in agroecology and sustainability policy; seed librarians; and most of all, North American seed savers wishing to gain a deeper understanding of the impact of neoliberal policy on their rights to save seeds in their farms and gardens.

\section{References}

Hayden, B., Canuel, N., \& Shanse, J. (2013). What was brewing in the Natufian? An archaeological assessment of brewing technology in the Epipaleolithic. Journal of Archaeological Method and Theory, 20(1), 102-150. http://dx.doi.org/10.1007/s10816-011-9127-y

Monsanto Canada Inc. v. Schmeiser. (2004). http://en.wikipedia.org/wiki/Monsanto Canada Inc. v. Schmeiser

Swiderska, K., Song, Y., Li, J., Reid, H., \& Mutta, D.. (2011, October). Adapting agriculture with traditional knowledge [Briefing]. London: International Institute for Environment and Development (IIED). Retrieved from http://pubs.iied.org/pdfs/17111IIED.pdf 